\title{
The Potato Association of America 104th Virtual Annual Business Meeting July 22, 2020, 4:00 - 6:00 pm ET
}

Published online: 25 February 2022

(c) The Potato Association of America 2022

1. The PAA Annual Business Meeting was called to order by the president, Kent McCue at 4:00PM ET on Wednesday, July 22, 2020 during the 104th Annual Meeting held virtually.

2. Remembrance of deceased members and friends.

- Creighton Miller

- Richard Wellington Chase

- Joseph J. Pavek

- Warren Henninger

3. President McCue called for additions to the agenda.

4. The minutes and reports of the 2019 PAA Annual Business Meeting were reviewed.

MOTION by Dennis Halterman, was seconded by Andy Robinson and unanimously passed to approve the minutes of the 2019 Annual Business Meeting.

\section{Officer and Staff reports}

a. President - Kent McCue provided a written report (see Appendix 1). Kent highlighted outreach activities of PAA through its involvement in Potato Expo and Spudman articles. Kent also acknowledged the effort of board members and AMR in the planning and execution of a successful virtual PAA annual meeting.

b. Treasurer - Larry Hiller reviewed the PAA's finances. Information is attached in Appendix 2 and is also included in the "PAA Members Only" section of the PAA website at http://potatoassociation.org

Highlighting the written report, Larry included a few observation on the virtual annual meeting and growth of the association. Some accounting highpoints of the year included transferring association accounting books to AMR control, and converting the credit card processing to Affinipay. Larry also highlighted that the implementation of the $\$ 800$ publication flat fee in August 2018 has been very successful. A few areas of emphasis for the coming year include: 1) endowment funds, payout, and uses, 2) maintaining membership and quality journal publication, and 3) developing future annual meeting planning guidelines for LAC operation in combination with AMR.

iii. Secretary - Darrin Haagenson provided a written report (see Appendix 3).

iv. Administrator - Angela Richardson provided a full written report to the "PAA Members Only" section of the PAA website at http://potatoassociation.org (see Appendix 4).

Angela highlighted AMRs continued operations role in PAA membership, finance, and communications, and the expanded involvement of the AMR Event Management Team in PAA annual meeting planning. Angela noted that the AMR office location is moving the end of July 2020 from Ann Arbor to Okemos, MI. Lastly, Angela completed training and an examination to become a certified association executive; this knowledge will be used to strengthen PAA in an ever changing landscape

\section{Standing Committee Reports}

a. Editorial Board - Samuel Essah provide a written report (see Appendix 5). Samuel reported that manuscript turn-around time is increasing, which can be attributed to difficulty in finding qualified reviewers for Senior Editors. Samuel is encouraging membership to assist Senior Editors in the review process. Average time for first decision is 76 days and final decision is 168 days. Samuel suggested a goal for a manuscript decision turnaround time would be a maximum 90-100 days from receipt to acceptance. Samuel reported the Journal Impact factor has decreased slightly in 2019 (0.858) from the five-year average (1.085), which may be attributed to the increased turnaround times. 
b. Finance - Larry Hiller provided written report (see appendix 2).

c. Leadership Identification and Development - Rich acknowledged two outgoing directors that completed their 3-year terms: Roy Navarre and Helen Tai. Elections for two new directors and a vice president appointment were coordinated with assistance of AMR.

d. Awards and Recognition Committee

i. Honorary Life Members - Rich reported the four inductees for Honorary Life Member Recognition include: Shelley Jansky, John Keeling, Jeff Stark, and Richard Veilleux. A formal 'virtual' recognition will occur at 5pm ET, July 22,2020 at the conclusion of the virtual annual business meeting.

ii. Frank L. Haynes Graduate Student Research Award - Paul Bethke reported that 10 students presented their live presentations at the beginning of the virtual annual meeting on July 20, 2020. Winners will be formally announced at the conclusion of the virtual annual business meeting.

\section{e. Association and Industry Outreach}

i. Promotion and Communication - Andy Robinson reported on the different social media channels being used to promote potato research and extension activities, and there are currently 265 Facebook, 629 Twitter, and 181 Instagram followers.

ii. Global Outreach In Peter VanderZaag's absence, Angela Richardson reported the international speaker, Marc Ghislain, scheduled for 2020 has been moved to 2021 and Peter will be coordinating in PEI 2021.

f. Membership - Mark Pavek reported that the 2019-20, membership included 305 individual, 25 sustaining, 39 student, 66 Honorary Life Members, and 14 Emeritus; totaling 449 members across 23 countries. This is a membership loss of approximately 20 members from 2018-19. The topic of annual meeting format (virtual) and relationship to membership decline was discussed, and Erin M. suggested surveying membership not participating in the virtual meeting.

g. Standing Rules Document - Mark Pavek reported that work is ongoing to update the document and Mark requested input from AMR and sought additional volunteers for assistance in reviewing.

h. Site Selection - Susie Thompson provided a written report (see appendix 6). The 2022 meeting plans in
Montana are ongoing. The PEI LAC is working closely with the host Delta hotel and convention center located in Charlottetown on 2021 annual meeting preparations. Should the pandemic delay an in-person 2021 meeting in PEI, the LAC and AMR have had successful discussions on future meetings in PEI. Susie reported that Oregon has presented plans for hosting a future PAA annual meeting, citing Portland or Bend as possible locations. A formal notice was forwarded to the Executive Board of Directors identifying Oregon as a tentative 2023 meeting location.

\section{Section Reports}

a. Breeding \& Genetics - Laura Shannon provided a written report (see appendix 7).

b. Extension, Production \& Management - Yi Wang provided a written report (see appendix 8)

c. Plant Protection - section meeting was postponed until in-person annual meeting returns in 2021.

d. Physiology - Amber Gotch reported the postponement of the physiology section meeting until 2021 with officer positions remaining the same until the 2021 in-person meeting in PEI.

e. Utilization \& Marketing - Tina Brandt reported that section officer positions will remain the same until 2021, with one exception: Darrin Haagenson was elected as new section secretary. The section hosted a brief virtual round table discussion on the impact of COVID on utilization and marketing of potato. (see appendix 9)

f. Certification - Gordon Henry provided a written report (see appendix 10).

\section{Board of Directors Actions: 2019-2020}

The dates following the approved motions below represent the BoD meeting where the action was approved with additional details provided in the minutes of those BoD meetings.

October 2019 - June 2020 - Kent McCue - Motions Passed

MOTION by Larry Hiller, was seconded by Jeff Miller, and was unanimously passed that the BoD approve two new savings accounts with the PNC bank in Ann Arbor in the name of 1) LAC Idaho and 2)Certification Section. These two saving accounts would fall under the PAA umbrella and will be assets of the PAA corporation, but will be separate savings accounts and will not fall under PAA annual budgeting. (10-15-19)

MOTION by Larry Hiller, was seconded by Jeff Miller, and was unanimously passed that the $\mathrm{BoD}$ approve a one 
year APEX Abstract software renewal for the 2020 annual meeting calendar year at a cost of $\$ 1,800$. (10-15-19)

MOTION by Larry Hiller, was seconded by Roy Navarre, and was unanimously passed that PAA begin using credit card payment transactions with Affinipay as the approved credit card processor in association with Wild Apricot, beginning with the PAA December 2019 renewal with Wild Apricot. (10-15-19)

MOTION by Larry Hiller, was seconded by Dennis Halterman and unanimously approved to continue financial transactions for administrative and operational procedures of the Potato Association of America into the beginning of 2020 if we do not have a fully executed and accepted revised budget for 2020. (11-19-19)

MOTION by Roy Navarre, was seconded by Larry Hiller and unanimously approved to renew the proposed AMR contract for 2020. (11-19-2019)

MOTION by Roy Navarre for the board to approve International Relations Committee speaker selection: Marc Ghislain, was seconded by Jeff Miller, and was unanimously passed (2-25-20)

MOTION by Jeff Miller to amend the 2020 budget line item 62500 symposium speaker budget allotment from $\$ 4,000$ to $\$ 6,000$, was seconded by Dennis Halterman, and was unanimously approved (3-17-20).

MOTION by Larry Hiller, was seconded by Dennis Halterman, and was unanimously approved to accept the proposed 2020 PAA annual budget as presented online (3-17-20).

MOTION by Larry Hiller, was seconded by Helen Tai, and was unanimously approved to use Swoogo for 2020 Annual Meeting registration processing (3-17-20).

MOTION by Larry Hiller, was seconded by Rich Novy, and was unanimously approved to provide build your own a la carte registration options for HLM and accompanying persons for the 2020 Annual Meeting (3-17-20).

MOTION by Roy Navarre, seconded by Rich Novy: To cancel the in-person annual meeting of the PAA for 2020 in light of the Covid pandemic situation. Unanimously Passed Via Email Vote. (5-4-20).

MOTION by Roy Navarre, seconded by Rich Novy: To accept the proposal of holding the 2022 meeting of the PAA in Missoula MT. Unanimously Passed Via Email Vote. (5-4-20).

MOTION by Larry Hiller, seconded by Addie Waxman: to accept the 4 director and 2 vice president nominees, and the motion was unanimously passed (5-19-20).

MOTION by Larry Hiller and seconded by Dennis Halterman: to delay the 2020 PAA symposium until 2021 and the 2021 PAA symposium until 2022, and that this information be conveyed as soon as possible to the organizers for benefit of their speakers and planning. Unanimously passed by email vote (5-21-20).
MOTION by Helen Tai, seconded by Larry Hiller: to list the PAA virtual annual meeting registration cost at $\$ 50$ per registrant, and the motion was unanimously passed. (6-1-20).

MOTION by Larry Hiller and seconded by Jeff Miller that PAA go with the AMR Zoom account, and additionally provide up to $\$ 1,000$ in the 2020 PAA budget for additional Zoom and related video conference programming technology features implemented by PAA, the motion was unanimously approved (6-16-20).

MOTION by Larry Hiller and seconded by Dennis Halterman that the 2020 PAA virtual annual meeting will occur within a block of time beginning Monday, July 20 and ending Thursday, July 23, 2020; motion unanimously passed (6-16-20).

\section{New Business}

a. Outstanding Section Paper of the Year - Samuel Essah. Each outstanding Section paper of the year was announced.

\section{Pathology:}

corresponding author: Jonathan L Whitworth

'Symptom Expression of Mainstream and Specialty Potato Cultivars to Bacterial Ring Rot (Clavibacter sepedonicus) and Evaluation of in-Field Detection'.

Jonathan L. Whitworth, Rachel A. Selstedt, Alan A. G. Westra, Phil Nolte, Kasia Duellman, S. K. R. Yellareddygari, \& Neil C. Gudmestad_

Breeding and Genetics:

corresponding author: Walter S. De Jong

'QTL for Resistance to Globodera rostochiensis Pathotype Ro2 and G. pallida Pathotype Pa2/3 in Autotetraploid Potato' . Jaebum Park, Christine A. Hackett, Louise-Marie Dandurand, Xiaohong Wang, \& Walter S. De Jong

\section{Entomology:}

corresponding author: W. Rodney Cooper

The Weed Link in Zebra Chip Epidemiology: Suitability of Non-crop Solanaceae and Convolvulaceae to Potato Psyllid and "Candidatus Liberibacter Solanacearum"

W. Rodney Cooper, David R. Horton, Eugene Miliczky, Carrie H. Wohleb \& Timothy D. Waters

\section{Production Management:}

corresponding author: Addie Waxman

'The Effect of Harvest Timing on French Fry Textural Quality of Three Processing Potato Varieties: Russet Burbank, Alpine Russet, and Clearwater Russet' Addie Waxman, Jeffrey Stark, Michael K. Thornton, Nora Olsen, Joseph Guenthner \& Richard G. Novy

\section{Physiology:}

corresponding author: Stef de Haan

'The Nutritional Contribution of Potato Varietal Diversity in Andean Food Systems: a Case Study' Stef de Haan, 
Gabriela Burgos, Reyna Liria, Flor Rodriguez, Hilary M. Creed-Kanashiro, \& Merideth Bonierbale.

Economics: no outstanding paper was awarded in 2019

\section{b. Announcement of Graduate Student Competition Winners- Paul Bethke}

1st Place: Ms. Rabecka Hendricks, University of Idaho, 'Susceptibility of Harvested and Stored Potatoes to Bruise; Extension, Production, and Management'

2nd Place: Ms. Fatemeh Ekbataniamiri, University of Maine, 'Investigating Surface Water in Association with Potato Blackleg and Soft Rot'

3rd Place: Ms. Thilani Jayakody, Michigan State University, 'Genome Sequence of DM1S1 as a Resource for Gene Editing in Diploid Potato and Detection of Genomewide Off-target Effects'

\section{iii. Recognition of Service to PAA: Outgoing Directors}

- Roy Navarre

- Helen Tai

\section{Announcement of newly-elected Vice-President and} Directors

- Vice President - Helen Tai

- Director - Brian Charlton

- Director - Sastry Jayanty

\section{Recognition of 2020 Honorary Life Members}

- Shelley Jansky (nominated by Paul Bethke)

- John Keeling (nominated by Bret Nedrow)

- Jeff Stark (nominated by Addie Waxman)

- Richard Veilleux (nominated by David Douches)

12. "Resolution of Appreciation" - Kent F. McCue

Recognition of Virtual Annual Meeting Hosts

The 104th virtual annual meeting was hosted by Association Management Resources (in particular Erin McLaughlin) and the planning and execution was also supported by the PAA Board of Directors (in particular, Secretary Darrin Haagenson). The Association greatly appreciates the members for their participation in our first virtual annual meeting.

Therefore, let it be resolved that on this 22nd day of July, we of the Potato Association of America extend our heartfelt and most sincere thanks toAssociation Management Resources, the PAA Board of Directors, sponsors, and all who contributed to the success of the virtual annual meeting. Please join me to acknowledge a job well done!

13. Passing of Gavel: The 104th Annual Business Meeting of the PAA concluded with the passing of the gavel from outgoing President Kent McCue to incoming President Mark Pavek.

\section{Adjournment}

MOTION: moved by Kent McCue, seconded by Rich Novy, and unaminously passed to adjourn the meeting at 5:40PM ET.

Respectfully Submitted,

Darrin Haagenson

PAA Secretary

\section{Appendix 1}

\section{President's Report - July 22, 2020}

I am pleased to welcome everyone to the annual business meeting of The Potato Association of America.

This year the financial and administrative affairs of the society continued their evolution in partnership with ARM, Association Management. In close cooperation with our Administrator Angela Richardson and members of the AMR team that have worked closely with the officers and members of your Board of Directors.

In the agenda you will see a list of the Motions passed by the $\mathrm{BoD}$ during the year. Many of which are mundane as to the efficient operation of Society Business. Others increase Society support for outreach and acknowledgement of our members.

Regular outreach activities continued including our participation at the Potato Expo with talks on the exhibition stage and poster session organized by our Vice-president Mark Pavek. We also continued our contributions to Spudman magazine with articles on topics pertinent to the seasonal publication from our members.

Preparation for the annual meetings is always an important aspect of our annual affairs. As the responsibilities of the Local Arrangement committees have decreased, we are now benefiting from the expertise of our partnership with AMR and Erin McLaughlin our conference coordinator.

This year as you all know we found it necessary to adapt to the Covid19 pandemic. This put an extra burden on the $\mathrm{BoD}$ and our partners at AMR. The result was a virtual meeting culminating in this virtual business meeting. Although this is not what any of 
us would have chosen it has been most successful and my thanks to everyone who made it possible and has participated with us.

As we move into the next year we will remain optimistic for an in-person meeting in PEI next year. However our primary concern will remain the health and safety of our membership. Mark Pavek and the new $\mathrm{BoD}$ will be closely monitoring events in America and around the world as planning progresses.

I will conclude with a thank you for having selected me to be your president for the past year. It has been an honor and a challenge, and I look forward to my continued contributions to the BoD and the Society in my role as Past-president.

Thank you.

Submitted by: Kent McCue, President

\section{Appendix 2}

\section{Treasurer's Report - July 22, 2020}

The financial health of the Association continues to remain in a favorable and positive status despite the current environment and current pandemic around the world. The Association continues operating with a positive fiscal balance in consideration of our fiscal year budget, bank accounts, savings and CD accounts, and our two endowments. The Treasurer's report this year covers the 2019 fiscal year, the different accounts, and the first half of the current 2020 fiscal year.

I wish to remind you once again and emphasize that the Association continues to have two principle sources of income $=$ memberships and the AJPR .

Status report and highlights since last annual meeting:

1. working and learning relationships between PAA and AMR continue positive and productive.

a. accounting and all financial transactions conveyed to AMR and conversion from Cash Accounting to Accrual basis.

2. 2019 records nearly ready to be transferred to CPA for filing of the 990 report. The pertinent reports are posted on the Members Only section of our website, I encourage you to review them and direct any questions and comments to myself and/or Angela.

b. Savings and three CD accounts continued to increase in value and return interest to the budget

c. the percentage of paid journal manuscript invoices increased but the number did decrease slightly

d. membership numbers, especially Individual and Sustaining decreased slightly
3. fully converted to credit card processor AffiniPay within the Wild Apricot program

4. combined two sections (Plant Protection and Certification) accounts into the PAA completely

5. established separate Money Market accounts for Certification Section and ID 2018 LAC

6. initiated the Registration waiver for Graduate Students attending the Annual Conference

7. developed additional section to FY Operating Budget to include the annual conferences

Observations and thought for the future:

1. continue to review and enhance plans for the Endowment payout funds

2. review membership recruitment efforts for all categories, notably Sustaining Members

3. complete preparation of operating procedures statement and manual, synchronize with ByLaws, considering committees, awards, symposium, and annual conference finances

4. evaluate manuscript invoice payment timing and relationship with Springer's Open Access

Submitted by Larry K Hiller, PAA Treasurer

\section{Appendix 3}

\section{Secretary's Report}

The responsibilities of the PAA secretary have greatly changed in the last few years. I am grateful for AMRs presence; notably the leadership and guidance of Administrator Angela Richardson and Event Manager, Erin McLaughlin.

The recording of monthly PAA teleconference meetings via StartMeeting or monthly Zoom meeting recordings have permitted me to report detailed minutes of all monthly and special Board of Director meetings.

One role of the secretary is to help organize the annual meeting agenda. However, with this year's scaled down virtual meeting and the great leadership from Erin and her team, little input was required on my behalf. A few emails pertaining to scheduling of technical papers were exchanged. For this year's virtual program, there were 20 general presentations, 10 graduate presentations, and 4 posters. Again, Erin and her team did a fabulous job of making the 2020 annual meeting a success.

Respectfully Submitted, Darrin Haagenson, PAA Secretary 


\section{Appendix 4}

\section{Administrator Report}

Mission: The Potato Association of America shall collect and disseminate scientific information relating to all phases of the potato industry, including, but not limited to, teaching, research, outreach, breeding, certification, production, pests, transportation, processing, and marketing and utilization.

\section{Membership}

- 2020 Memberships: 410 (Renewals), 35 (New) Processed in Wild Apricot

- 445 Springer AJPR Codes Emailed to 2020 Membership

- Provided support as needed to members with Wild Apricot, website and general virtual meeting questions

\section{Financial}

- AJPR Invoicing for accepted manuscripts (August 2019-July 2020)

- Followed up on delinquent manuscripts for 2019

- Worked with PAA Certification Treasurer Kent Sather and PAA Treasurer Larry Hiller to transfer this bank account under the PAA - provided necessary financial reports to K. Sather

- Certification Dues Section Invoicing for 2019

- Worked with AMR staff on PAA monthly financial report clarifications

- Affinipay processor was activated and put into place as PAA's primary credit card processor by December 2019

- Worked with the Idaho LAC and Larry Hiller to transition their LAC funds under the PAA

\section{Communications}

- 66 E-blasts in the form of various PAA Announcements and Job Posting has been shared

- Board of Directors transitioned to utilizing Zoom for monthly calls

- Finalized new PAA brochure and prepared for mailing for Potato Expo 2020

\section{Annual Meeting}

Montana 2020 Annual Meeting/Virtual Meeting

- Due to Covid-19, this meeting has been moved to July 2022 at the Holiday Inn Downtown Missoula

- Worked with PAA event manager Erin McLaughlin to transition this year

- Connected with Section Leaders regarding scheduling virtual meetings during July 20-23, 2020
Prince Edward Island 2021Annual Meeting

Conference call with PEI LAC and AMR's PAA Event Manager, Erin McLaughlin in December 2019 to discuss meeting logistics

- Provided Ryan Barret with funding lists from 2017-2018

\section{Clerical}

- HLM Voting

- Board Elections Voting

- Surveys to membership regarding the virtual annual meeting

\section{Website Updates}

- Sections and Board of Directors 2019-2020

- Annual/Virtual Meeting

- Potatoes USA - creation of Google Form for submissions with Shawn Detlor

- Honorary Life Members Section

- Job Postings

- AJPR Journal Updates

- Annual Meeting Updates

- Seed Acerage

\section{Social Media}

- Facebook Likes: 243

- Facebook Followers: 265

- Twitter Followers: 629

- Instagram: 181

\section{Professional Development}

- Certified Association Executive Candidate -July 2020 - Commitment to association management practices in areas such as strategic leadership, financial management, membership development, marketing and branding, knowledge management

Respectfully Submitted: Angela Richardson, Administrator

\section{Appendix 5}

\section{Editorial Board}

1. The turn around times appear to be increasing due to difficulty in finding qualified reviewers.

The reviewer invitation acceptance rate for January - May, $2020=45.8 \%$. 
Average days to first decision $=76$ days.

Average days to final disposition - Accept $=168$ days.

Editorial Board will meet on Thursday and will address this to reduce the number of days to first decision and final disposition.

2. We had a slightly lower impact factor for $2019-0.858$. This was mainly due to submissions to the journal which has been on a downward trend in recent year.

We will have to introduce special issues, review articles, or invited articles to help reverse the trend in submissions.

5 -Year IF up to $2019=1.085$

3. 2019 Acceptance rate $=51 \%$

Rejection $=40 \%$

Withdrawal $=9 \%$

Respectfully Submitted, Samuel Essah, Editor in Chief

\section{Appendix 6}

\section{Site Selection Committee Report}

The Site Selection Committee (SSC) met at 2 p.m. central time on Friday, July 17, 2020 via Zoom. Committee members attending included Susie Thompson (Chair), Gary Secor (2017 North Dakota LAC), Tracy Schinners-Carnelly (2019 Manitoba LAC), Ryan Barrett (2021 PEI LAC), Vidyasagar 'Sagar' Sathuvalli (Oregon State University), and Angela Richardson and Erin McLaughlin from AMR.

The 2020 meeting agenda and the 2019 Report to the Executive Committee were reviewed and approved.

Updates for the 2020/2022 meeting in Missoula, MT were provided by Erin. They are working on sponsorships particularly at this point. Ryan then covered the PEI plans for 2021. Committees are formed and functioning. Events at the Delta Prince Edward are being planned, a lobster feed in the works one evening off-site, and tour ideas are being garnered and considered. Contingency plans for 2023 seem an option if the meeting needs to move ahead as Montana did in 2020.

A letter of request and formal proposal to host the annual meeting in 2023/2024 were received from Sagar Sathuvalli and Brian Charlton representing the Potato Industry in Oregon. They are considering Portland and Bend as sites. The committee discussed advantages and disadvantages of both, and tour options. Tracy moved (Gary 2nd) we recommend the PAA EC accept the invitation from Oregon.

With the small group and no new business to discuss, suggestions for future meetings include Wisconsin, Pennsylvania, Ontario and Alberta.

The meeting adjourned at 3 p.m. central time.
Respectively Submitted,

Susie Thompson

\section{Appendix 7}

\section{Breeding and Genetics Section Minutes}

\section{Agenda items}

Dave made motion to approve minutes

Cari seconded

Meeting minutes from last year approved.

Cari to suggest everyone put e-mails in the comments which we did

Sagar has an addition to the agenda for a special edition of the paper for Genes

Jeff to add an agenda item of an $\mathrm{R}$ package

Annual meeting update for 2021

Dennis

Symposium update and annual meeting

Next meeting will be in PEI. Symposium on diploid breeding will be next year in person to allow more interaction with speakers in person.

Shelley Jansky was in charge for the symposium this year and since she is retiring, Dennis is taking over for next year.

All speakers are changing from this year to next year in PEI.

Speakers for next year

Walter DeJong

David Francis

Jiming Jiang

Jeronme (last name?)

Joshua Parsons

Diploid breeding SCRI update from Jeff

Had advisory board meeting yesterday.

Nearing end of 1 st of 4 years.

Short, couple page summary of year 1 accomplishments and next year goals was made/presented. If you want a copy, e-mail Jeff.

PanGenome update - Jeff

Money worked out and consortium agreement fully worked out.

6 tetraploid varieties included

All data shared between all partners.

Manuscript is being targeted for early next year.

Intertek platform update - Jeff

Excellence in breeding program initiative from Gates Foundation. Working on high throughput genotyping. Initial push to offer KASP genotyping service linked to traits with high penetrance.

Intertek converted PVY markers for Ryadg and Rysto

H1 failed

Community adding others 
Up to 10 SNPS in 384 well format at $\sim \$ 2.50$ per sample

R2 added for LB resistance in Payette Russet

David DeKoeyer - Ryadg, Rx, others in process. They are using historical data to validate the markers vs. new phenotyping. They do have $\mathrm{H} 1$ and $\mathrm{Rx} 1$.

CDF, DFR, Developer locus are in process.

Jeff asked what to work on.

Rychc? From Rich and Jonathan

Han Tan suggested sli genes - Dave's group is validating and will put best on the platform.

Corky Ring spot - Sagar is in process of validating a marker for it and Joe mentioned TRV resistance from Castle Russet - Are these the same loci/markers?

What about wart resistance? Rich thinks it would be a good idea.

R8 - two markers from CIP but don't work well so that would be another to focus on.

Dave - sampled 1,000 tubers using a "tuber hole punch" recommended by Helen Tai. Seemed to work fine with their samples.

Laura did tuber and leaf samples from 94 samples and got the exact same missing data range.

Dave - Intertek has been reliable, responsive, and is a good company to work with.

Intertek does not do a good job calling dosage, something they know, but something they are also working on. You can look at the XY data like you look at an Array and make manual calls.

\section{Intertek Mid density - Jeff}

Intertek is the service provider, but they just do the DNA extraction cheaply and ship out the DNA. For the mid density they are partnering with DaRT. DaRTag is a multiplexed PCR amplicon sequencing approach.

Get read counts for each sample at each locus and then they do the SNP calling.

Subset of markers from the SNP array.

Initial advertisement was between 1,000-4,000 markers. DaRT is pushing numbers closer to 1,000 vs. 4,000 .

Price for DaRTag service is $\$ 11$ per sample in increments of 386 .

Started with 1,500 and then 800 worked. Jeff had array data and also DaRT tags and about half of them gave good dosage in the initial pilot. 500 markers ended up working well.

Starting again to use V3 array markers and sent in 2,500 new SNPs to add to the 500 that worked well. DaRT has committed to 1,500 markers that show accurate dosage at $50 \mathrm{x}$ or more. Main goal is to use for genomic selection.

Can also migrate trait markers from KASP to DaRT so you only need to run one assay.

\section{Sagar - special issue of Genes}

Genes journal is open access and want a special edition on potatoes and potato breeding. It is an open access journal and submissions are officially due in October but could be extended to December.

\section{Jeff and $R$ package}

Jeff has a GitHub page and has packages there. Package and guide on how to use it.

Has interesting examples for tetraploids and dihaploids. 2,000 genotypes go into calling the SNPs from the array.

\section{NCCC215 meeting}

Chicago meeting is going to be virtual. Platform TBD. Dates are December 7,8.

Is the north central meeting but has historically been opened to anyone who can come. Being virtual we could allow more/wider access, but we will maybe have to be more organized.

\section{Cari - vice chair \\ Josh - secretary}

Secretary for 2021

Sagar suggests Max, and Rich seconds that. Lots of thumbs up. For the record, Max is not present.

\section{Polyploid SCRI}

Jeff - Polyploid genetic prediction grant is approved for funding and will be kicking off. SCRI is now supporting both tetraploid and diploids.

David Burn is the rose breeder and is the lead. Focus is genomic selection and DaRT platform is hopefully going to be a main tool.

\section{Adjourning}

Motion to adjorn Helen - Rich seconded - lots of thumbs up

\section{Attendees}

Laura Shannon I Imshannon@umn.edu

Joseph Coombs I coombs@msu.edu

David Douches I douchesd@msu.edu

Cari Schmitz Carley I cari.schmitz-carley@ aardevo.com

Samuel Gagnon I samuel.gagnon.19@ulaval.ca

Jeffrey Endelman I endelman@wisc.edu

Natalie Raissa Kaiser I kirkwyla@msu.edu

Thilani Bhagya Jayakody ljayakod1 @ msu.edu

Dave Holm I spudmkr@gmail.com

Sarah Lee I leesara9@msu.edu

Kirk Amundson I kramundson@ ucdavis.edu

Helen Tai I helen.tai@canada.ca

Maria Caraza-Harter I maria.caraza@ wisc.edu

Lin Song I lsong27@wisc.edu

Peyton Sorensen I psorensen@wisc.edu

Tom Salaiz IThomas.salaiz@mccain.com

Justin Kadi I borna@ climate.ai

Dennis Halterman IDennis.halterman@usda.gov

Sagar I vidyasagar@Oregonstate.edu

Joe Kuhl I jkuhl@uidaho.edu

David DeKoeyer I david.dekoeyer@canada.ca

Kate Shaw Imcglewka@msu.edu

Alfonso Del Rio I adelrioc@wisc.edu 
Luke Thurgood I luke.thurgood@ simplot.com

NManrique In.manrique@ cgiar.org

Shelley Jansky Ishjansky.sj@ gmail.com

Noelle Anglin

Rich Novy I Rich.Novy@usda.gov

Jonathan Whitworth ljonathan.whitworth@usda.gov

Respectfully Submitted,

Laura Shannon

\section{Appendix 8}

\section{Extension, Production and Management Section Minutes}

Minutes - 2020 Virtual Meeting of the Extension, Production \& Management Section

Attendees: Yi Wang, Erin McLaughlin Carl Rosen, Ryan Barret, Amber Gotch, Andy Robinson, Angela Robinson, Art Espinoza, Asunta Thompson, Bob Leiby, Carrie Wohleb, Christopher Cross, Darrin Haagenson, Jeff Miller, Jeff Stark, Larry Hiller, Luke Thurgood, Lynn Woodell, Mark Otto, Mike Thornton, Nora Olsen, Pam Hutchinson, Pat Slininger, Sage McClintick, Tina Brandt, Susannah Cooper, Rhett Spear

1) Called to order

2) Intros

3) Approve minutes

a. Moved: Susie Thompson

b. Seconded: Jeff Miller

\section{4) Announcements}

Operation of PAA and the extension, production and management section during the pandemic:

Updates on 2021 and 2022 annual meeting: uncertain at this point, $2021 \mathrm{PEI}$ and 2022 Missoula, MT, but things can change depending on the situation of the pandemic and travel restrictions, 2023 annual meeting was supposed to be held in Oregon, but decisions won't be made until situation becomes clear for 2021 and 2022.

\section{According to Editor-in-Chief Samuel Essah:}

AJPR impact factor keeps going down, hard to find reviewers, turnaround time becomes longer, encourages our section members to conduct reviews, encourage submission to AJPR, now there is an open access option, Samuel also encouraged more review papers, which is one way to increase impact factor.

Starting from this year, there will be one "Outstanding Paper of the Year Award" for each section.
5) Symposium for the 2021 and 2022 Annual Meetings

2021 (was scheduled for 2020): "Diploid Breeding" (Breeding and Genetics and Plant Protection sectionsChairs: Dave Douches/Shelley Jansky/Dennis Halterman)

2022 (was scheduled for 2021): "Life-Cycle of the Potato" (Physiology Section-Chair Paul Bethke).

Potato Soil Health for 2023 (Extension, management and production sponsorship).

Carl Rosen, Mike Thornton and Ryan Barret will meet to work on a short proposal that will be submitted to the board to review (tentatively in October of 2020). The proposal needs to be submitted in order to be considered two years prior to its occurrence year.

\section{6) Area reports}

WA (Carrie): Slow spring or normal spring, pretty wet June but no severe disease has been reported in the whole Columbia Basin, maybe just no inoculum this year. Earlier start to the potato psyllids, nothing alarming, haven't have the extreme heat days, no hotter than 95F so far. Covid-19 processing company pulled back some contracts, some acreages have been put in without any contracts

ID (Mike Thornton/Nora Olsen/Pam Huntchingson): Second wettest June so far, but no disease yet, early digs yield and size decreased because of lower growing degree days, but overall pretty good. Disease issues very quiet. Herbicide injury issue is not happening this year, potato recovered.

ND, MN (Andy Robinson/Carl Rosen/Susie Thompson): Planting looks good, a week or so late, fresh market potato acreage down, things been good until the last couple of weeks. Early blight and late blight disease pressure are high. Standing water on NDSU campus, hot and wet, high frequency of rain is really an issue

WI (Yi Wang): has been a normal year so far. After two seasons with extreme weather conditions, a normal year is much appreciated. Things look decent at this point. No late blight.

MI (Mark Otto): A lot of volunteer potatoes around, hard to control in the heat, June has the most sun ever, early dying issues start to show up

ME (Susannah Cooper): so far the crops look good 13. website info needed for USDA SCRI funded research - there is no info on this link; The Chair encourages everyone to submit info to PAA to get our info out there

NY (Bob Leiby): no late blight, a little bit of early blight. Appearance of blackleg was delayed by one month, from early June to July 9 or 10.

Canada(Ryan Barret) PEI: down on French fry, up for fresh market, very dry and warm so far, so far yield and set is average to above average, weed problem is a big issue due to the dry weather Manitoba: Winnipeg area 
has been wet, but no late blight issues so far. In Alberta, most declined acreage of processing potatoes, cooler than normal weather, two significant hail issues, causing damage to the plants, Ontario hot to very hot until they start to get rain around July 15, Quebec has seen significant increase of acreage, overall the plants look decent, but really needs rain

\section{7) Other items}

Ryan Barret asked for input from the section members about plans for tours at the PEI annual meeting.

\section{8) Nominations and election of officers for 2021}

Rhett Spear - nominated for secretary Jeff Miller moved to approve nomination; seconded Vote - ayes have it!

9) Jeff moved to adjourn. seconded

Respectfully Submitted, Yi Wang

\section{Appendix 9}

\section{Utilization and Marketing Section Minutes}

Attendees:

Tina Brandt tina.brandt@simplot.com

Jolyn Rasmussen: jolyn.rasmussen@ simplot.com

Cari Schmitz Carley: cari.schmitz-carley @ aardevo.com

Darrin.Haagenson: Darrin.Haagenson@usda.gov

Amber Gotch: amber.gotch@wisc.edu

Francisco Bittara: Francisco.bittaramolina@simplot. com

TIM KAZMIERCZAK: timothy.kazmierczak@usda.gov David Holm: spudmkr@ colostate.edu

Alfonso Del Rio: (Alfonso del Rio) adelrioc@wisc.edu

Bob Leiby rleiby@pacooppotatoes.com Pa Cooperative

Potato Growers, Inc.

Oluwafemi Alaba: oluwafemi.alaba@ maine.edu

Nora Olsen: norao@uidaho.edu

jedgrow: jed.grow@ndus.edu

\section{Call to Order and Welcome}

Chair, Tina Brandt, called the meeting to order at 11:30 a.m. Eastern Time

\section{Introduction of Officers and Attendees and Virtual Sign In}

Officers: Chair: Tina Brandt, Vice Chair: Colton Thurgood (resigned as unable to fulfill the role), Secretary: Joe Townsend (WSU grad student - unable to attend)

3. 2019 Minutes- Minutes were briefly discussed. Motion to approve minutes made by Jolyn Rasmussen, seconded by Bob Leiby. Vote was taken and passed unanimously.

PAA President requested discussion of 2 Announcements:

- Editorial Board - increase visibility rating as a Journal, need to be quicker on reviews. Need reviewers, please consider reviewing papers.

- Reminder to attend Business Meeting later in the day.

\section{2020 Pre-PAA Section Meeting Online Survey Results}
a. Hold online meeting
b. No guest speaker
c. Rollover current officers for 2021

5. Vacancy in position of Secretary:

a. Oluwafemi Alaba nominated: Darrin Haagenson. Was seconded by Bob Leiby. Vote was unanimous.

6. Open Forum Discussion Topic: "Effects of COVID 19 Pandemic on Marketing and Utilization of Potatoes"

Tina Brandt with J.R. Simplot Co. provided comments regarding Frozen fry market. Nora Olsen, reported on fresh potato demand and shift in delivery methods.

Meeting Adjourned at 11:50 am.

Respectfully submitted, Tina Brandt

\section{Appendix 10}

\section{Certification Section Update}

Typically, the Certification Section of the PAA would hold an in-person meeting in either late November or early December. Where possible, the Section Meeting would occur during the same week as the Canada-United States Potato Committee meeting (co-chaired by the Canadian Potato Council (CPC) and National Potato Council (NPC)) and other relevant meetings to facilitate attendance to multiple meetings. Canada-United States Potato Committee meeting will not be held this year; CPC and NPC are considering to hold this meeting every second year.

The 2019-2020 Certification Section committee members are planning to have a conference call on either July 28 or August 6 to consider hosting a virtual section meeting this 
winter. Although not confirmed, it appears unlikely that an in-person meeting will occur due to the uncertainty presented by Covid 19 and related travel restrictions.

2019-2020 Committee Certification Section members

Chair: Gordon Henry, Canada

Vice Chair: Adam Winchester, Nebraska

First Year Director: Kay Oakley, Washington
Second Year Director: Eric Byre, Minnesota

Secretary: Nina Zidack, Montana

Treasurer: Kent Sather, North Dakota

Respectfully Submitted,

Gordon Henry 